\title{
技術論文
}

\section{過冷却保存されたカットホウレンソウの 電気的，生理学的評価}

\author{
小出章二 ${ }^{1 *}$ ，大須賀玲 ${ }^{1}$ ，折笠貴寛 ${ }^{1,2}$, 上村松生 ${ }^{1}$ \\ 1 岩手大学農学部 \\ 2 次世代アグリイノベーション研究センター, 岩手大学
}

Evaluation of Electrical and Physiological Properties of

Supercooled Fresh Cut Spinach

Shoji Koide ${ }^{1 *}$, Rei Ohsuga ${ }^{1}$, Takahiro Orikasa ${ }^{1,2}$ and Matsuo Uemura ${ }^{1}$

${ }^{1}$ Faculty of Agriculture, Iwate University, 3-8-18 Ueda, Morioka 020-8550

${ }^{2}$ Agri-Innovation Center, Iwate University, 3-8-18 Ueda, Morioka 020-8550

\begin{abstract}
In this study, the freezing point of fresh cut spinach was calculated from measured values of osmolality, and the supercooling point was determined from the cooling curve obtained by differential scanning calorimetry (DSC). The freezing point was $-0.95 \pm 0.19^{\circ} \mathrm{C}$, and the supercooling point ranged from $-7.1^{\circ} \mathrm{C}$ to $-16.8^{\circ} \mathrm{C}$. Next, a fresh cut spinach sample was packed in film, heat-sealed, and subjected to a supercooling test at $-5^{\circ} \mathrm{C}$ for 1 week. After supercooling, the state of the cell membranes and cell viability of the sample were evaluated using an electrical impedance method and a triphenyl tetrazolium chloride (TTC) method, respectively. The supercooling test indicated that 45 of 48 samples had intact cell membranes and demonstrated cell viability. The present study showed that fresh cut spinach can be kept in a supercooled state at $-5^{\circ} \mathrm{C}$ for 1 week; however, there were some changes in the state of the cell membranes and a decrease in cell viability during supercooling.
\end{abstract}

(Received Dec. 19, 2018; Accepted Mar. 12, 2019)

Keywords : supercooling, spinach, supercooling point, impedance, triphenyl tetrazolium chloride method キーワード：過冷却，ホウレンソウ，生存率，インピーダンス，TTC 還元法

低温は，青果物の呼吸と水分蒸発を抑制して，成分の消 耗を防ぎ微生物の繁殖を防ぐので，鮮度・品質保持の基本 である。青果物は, 低温障害を起こしやすいものを除くと, その最適貯蔵温度は $0{ }^{\circ} \mathrm{C} \sim 4^{\circ} \mathrm{C}$ 程度とされ, 水結点以下の 温度では, 一旦凍結すると凍結傷害が生じ品質が劣化する。 これに対し近年，過冷却状態を保ったまま青果物を保存さ せる過冷却保存の研究が進められている ${ }^{122)}$. この過冷却保 存は先行例 ${ }^{334)}$ があり，ニンニクの小鱗茎を氷結点以下の温 度で一定時間保存しても，その間に過冷却解消や凍結傷害 が見られなかったことが報告されている。過冷却（凝固点 以下になっても凝固せず, 液体で存在している状態）は生 物の重要な凍結回避機構の一つとして考えられているが, 青果物における過冷却状態は不安定なものとされ，振動な どの物理的なショックで容易に解消される。しかし今後, 過冷却状態の安定化が可能となり, 水結点以下でも水から 水への相変化を起こすことなく保存することができれば, 生鮮青果物の低温保存の一つの手法として過冷却保存は有
効な手段になると思われる。近年，著者らはカットキャベ

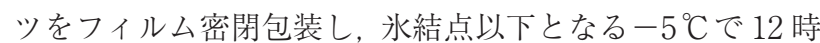
間保存したところ, 試料は過冷却状態を保つこと, 電気イ

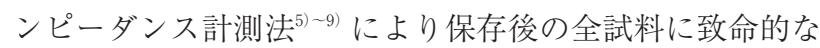
細胞膜損傷が見られないこと,またTTC 還元法(10)11) を行っ たところ全ての試料に細胞活性を有することを示した ${ }^{\mathrm{i} 122}$. しかし，青果物の過冷却状態を長時間安定化させた報告例 は見あたらない。

本研究では, 葉菜類のモデル材料としてホウレンソウを 用い, カットしたホウレンソウ試料の水結点を計測した質 量モル濃度を用いて算出するとともに，過冷却点を Differential scanning calorimetry (DSC) 冷却曲線より計測した. つぎに試料をフィルム密閉包装し， $-5{ }^{\circ} \mathrm{C} て ゙ 1$ 週間過冷却 保存させた。その後, 電気インピーダンス計測法 ${ }^{5)}$ (9) によ り得られたCole-Cole プロットの円弧の有無から試料の細 胞膜状態を検討するとともに, 植物の凍結による生死判断 に関する生理学的評価法の一つである TTC 還元法 ${ }^{1011)}$ を 
用いて細胞活性を評価したので報告する。

\section{実 験 方 法}

\section{1. 供試材料}

盛岡市内の量販店にて 2018 年 10 月から 11 月に購入し たホウレンソウ（Spinacia oleracea L.）を実験室に直ちに 搬入し，3 時間インキュベータ内 $\left(5^{\circ} \mathrm{C}\right)$ にて暗黒下で保存 した，その後，傷や目立った損傷のない葉を取り出し，こ れから大きな葉脈を除いて円形状試料（直径 $17 \mathrm{~mm}$ ）をコ ルクボーラーにより作成し，測定用試料とした。試料は, 成型後直ちに密閉可能なビニール袋（ユニパック B-4, 生 産日本社株式会社）に試料間の接触を防ぐように入れヒー トシールした. $105^{\circ} \mathrm{C}-24$ 時間法で測定した試料の初期水 分は $89.0 \pm 1.3(\%, w b)$ であった。

\section{2. 過冷却保存試験}

試料の入った袋を $-5{ }^{\circ} \mathrm{C} に$ 設定したインキュベータ (LHU-113，エスペック株式会社）内に置いておいたポリプ ロピレン製容器（Neo keeper，岩崎工業株式会社：容積 2.2 L）内に静置して冷却し，1 週間保存した.ここにインキュ ベータの扉の開閉に要する時間は, 試料温度が $0{ }^{\circ} \mathrm{C}$ から $-2^{\circ} \mathrm{C}$ の間を通過するときの冷却速度が約 $2^{\circ} \mathrm{C} / \mathrm{min}$ とな るように 10 秒以内とした。保存開始から 1 週間経過後, 試料をインキュベータから取り出し常温に戻した。その 後, 試料の細胞膜状態を電気インピーダンス計測法 ${ }^{5) ~ 9)} に$ より，細胞活性を TTC 還元法 ${ }^{1011)} に よ り$ 評価した。測定 は 3 反復行った

\section{3. 測定項目}

食品の水結点や過冷却点を求めるには熱電対を用いるの が一般的である ${ }^{13}$. しかし今回測定に供試したホウレンソ ウは，葉菜類のなかでも厚みが薄いため，試料の温度変化 を熱電対により計測とすると熱電対が氷核形成を誘発する ことで水結点や過冷却点に影響を与える可能性は高いと考

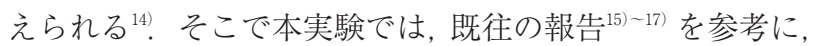
氷結点をオズモメータにより得られた質量モル濃度から算 出し, 過冷却点は DSC 冷却曲線から計測した。

(1) 凍結点

試料をエッペンチューブ内に入れ，これを液体窒素に浸 漬し凍結後解凍させた。その後, 試料をホモジナイズした 後に遠心し, この上澄み液の質量モル濃度 $(\mathrm{mol} / \mathrm{kg})$ を才 ズモメータ（5520 型, ウエスコ社, USA）により測定し, 次式から水結点降下度 $\Delta t\left(^{\circ} \mathrm{C}\right)$ を算出し, 凍結点を求めた。

$$
\Delta t=k \cdot w / m
$$

ここで, $w$ は溶媒 $1 \mathrm{~kg}$ 中に溶けている溶質の質量 $(\mathrm{kg})$, $m$ は溶質の分子量, $k$ は溶媒の種類により決まる定数であ り，水の場合 $1.86\left(\mathrm{~kg} \cdot{ }^{\circ} \mathrm{C} / \mathrm{mol}\right)$ である.

(2) 過冷却点

ホウレンソウを耐圧性アルミニウムパン（外形 $\phi 7 \mathrm{~mm}$ $\times 5 \mathrm{~mm}$ ：島津製作所株式会社）に入るように成形した。成 型試料をパンに入れた後, セルクリンパによりシールした。 過冷却点は DSC（DSC-60 Plus, 島津製作所株式会社）を用 いて窒素䨌囲気下で測定した。冷却速度は過冷却保存試験 時の試料の温度変化を考慮して $1{ }^{\circ} \mathrm{C} / \mathrm{min}$ と $2{ }^{\circ} \mathrm{C} / \mathrm{min}$ と し， 5〜 - $25^{\circ} \mathrm{C}$ の範囲で DSC 測定を行った。測定終了後, 附属のソフトウェアを用いて DSC 曲線において試料の過 冷却状態の解消による潜熱放出が開始する直前の温度を過 冷却点とした。

(3) 温度変化

$\mathrm{T}$ 型熱電対を試料内部に挿入できる厚みの葉脈を有す る試料に挿入し, 試料とインキュベータ庫内の温度変化を データロガー (midi Logger GL220, グラフィック株式会社) に記録した。この試料の温度変化の測定は上述した過冷却 保存試験と同じ条件下で別途行った。

(4) 電気インピーダンス

青果物の細胞膜の状態を測定する方法として電気イン ピーダンス計測法が知られている ${ }^{5)}$ ． 本研究では，電気イ ンピーダンス計測法により過冷却保存後の試料のインピー ダンスの周波数依存性を測定するとともに, Cole-Cole プ ロットを作成し細胞膜の状態を生鮮試料（サンプル成型直 後の生鮮試料，以下 $\mathrm{F}$ と称す）および凍結後解凍した試料 （以下，DS と称す）と比較した。 DS は F を密閉可能な袋 に入れ， $-80^{\circ} \mathrm{C}$ に保ったディープフリーザー（マイバイオ VT-78，日本フリーザー株式会社）16 時間凍結させ，その 後解凍したものであり，細胞膜が致命的に損傷した試料の コントロールとして用いた。

電気インピーダンスの測定は，既往の報告6) に準じて 行った。すなわち LCR メー夕（3532-50，日置電機株式会 社）に接続したステンレス製の $\phi 0.5 \mathrm{~mm}$ 針状電極を 10.0 $\mathrm{mm}$ の間隔で試料に貫通させ，複素インピーダンスの大き さ $|Z|$ と位相角 $\theta$ を計測した。試料に印加した交流電圧 は $1 \mathrm{~V}$ とし， $42 \mathrm{~Hz} \sim 5 \mathrm{MHz}$ の範囲における 50 点の周波数 で掃引測定を行い，計測された $|Z|$ と $\theta$ からレジスタンス $R(\Omega)$ とリアクタンス $X(\Omega)$ を算出した ${ }^{6}$. その後, 得ら れた各測定周波数におけるレジスタンスおよびリアクタン スから Cole-Cole プロットを作成した。

（5）細胞活性

植物の凍結による生死の評価法の一つである TTC 還元 法 ${ }^{1112)}$ を用いて試料の細胞活性を求めた。測定は, 電気イ ンピーダンス計測を行った直後の試料を小型試験管（16.5 $\times 105 \mathrm{~mm}$ ）内に入れ，0.05 M リン酸緩衝液（pH7.4）に溶 解した $0.6 \%$ TTC 溶液を $10 \mathrm{~mL}$ 加えたのち，試験管の口 にゆるく蓋をし，デシケータに入れ，真空ポンプで脱気し た. 脱気後 $25^{\circ} \mathrm{C}$ の暗黒下で 16 時間反応させた後, デシ ケータから試験管を取り出し，ディスクを純水で 2 回洗浄 した後，95\%エタノールを $7 \mathrm{~mL}$ 加え， $80^{\circ} \mathrm{C}$ に保った恒温 水槽内で 30 分間加熱した ${ }^{10111}$. 加熱後，抽出液に $95 \%$ エ夕 
ノールで $4 \mathrm{~mL}$ にメスアップレ, Sulpice らのホウレンソウ の細胞活性の測定方法 ${ }^{18)}$ に準じて, $520 \mathrm{~nm}$ の吸光度を分 光光度計 (V-630, 日本分光株式会社) で定量し，得られた 值を DS の吸光度の平均值で引き，これを $\mathrm{F}$ の吸光度の平 均值で除した值を細胞活性比とした。

\section{4. 統計処理}

本実験で測定して得られたデータは平均值士標準偏差と して示した，統計処理は，統計ソフト（エクセル統計 ver 2.13，社会情報サービス株式会社）を用いて行った．2群間 の比較は $\mathrm{t}$ 検定により, 細胞活性比については TukeyKramer 法を用いた多重比較試験により群間の有意差を検 討した，有意差の判定は有意水準 5\%で行った。

\section{実験結果および考察}

\section{1. 凍結点および過冷却点}

(1) 凍結点

オズモメー夕を用いて得られた質量モル濃度は $0.51 \pm$ $0.10(\mathrm{~mol} / \mathrm{kg})$ であった $(n=6)$.これより凍結点は -0.95 $\pm 0.19^{\circ} \mathrm{C}$ と算出された

（2）過冷却点

冷却速度 $2^{\circ} \mathrm{C} / \mathrm{min}$ のときの試料の DSC 曲線の一例を Fig. 1 に示す。これを見ると冷却過程において $-14.8^{\circ} \mathrm{C}$ 付 近に 1 つの発熱ピークが認められる。この発熱は, 試料の 過冷却状態が解消することにより試料内の水が凍結し潜熱 が放出した結果であり，発熱直前の温度は試料の過冷却点 である. DSC 測定により得られたホウレンソウの過冷却 点は, 冷却速度 $1{ }^{\circ} \mathrm{C} / \mathrm{min}$ のとき $-8.6{ }^{\circ} \mathrm{C} \sim-14.8^{\circ} \mathrm{C}(n=9)$, 冷却速度 $2^{\circ} \mathrm{C} / \mathrm{min}$ のとき $-7.1^{\circ} \mathrm{C} \sim-16.8^{\circ} \mathrm{C}(n=13)$ の值

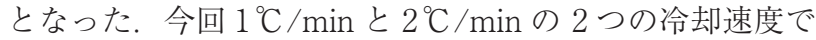
得られた過冷却点に有意な差は見られなかった。青果物の 過冷却点については，ブロッコリー，ニンジンおよびカリ

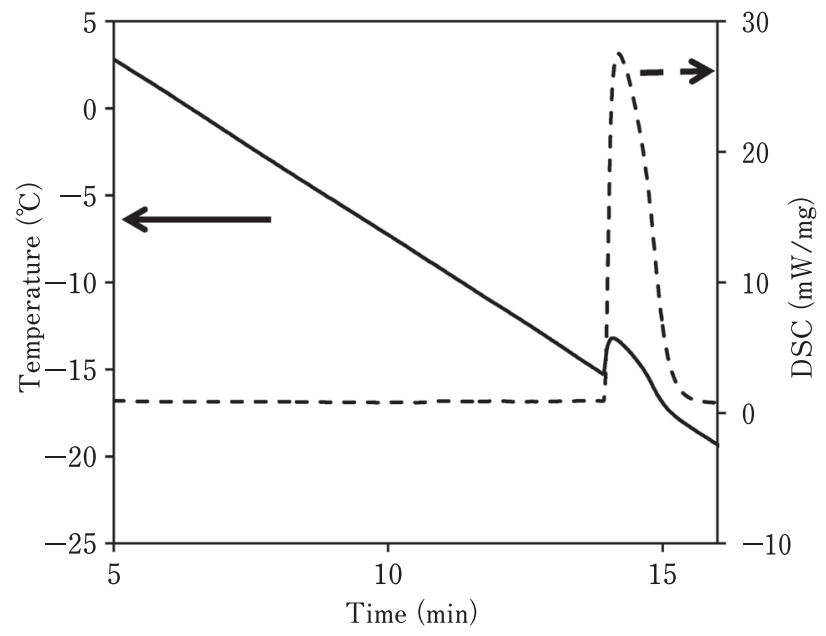

Fig. 1 DSC cooling curve of fresh cut spinach sample The solid line represents the temperature profile, and the dashed line the DSC exotherm.
フラワーではー $4.4 \pm 2.4{ }^{\circ} \mathrm{C}, \quad-2.7 \pm 0.8^{\circ} \mathrm{C}, \quad-5.2 \pm 2.6{ }^{\circ} \mathrm{C}$ と 報告) されているが, これらは熱電対による計測值である. 過冷却点の測定值は，熱電対での温度計測ではサンプルの 性状，センサの直径や挿入位置など多くの要素が測定值に 影響すること ${ }^{19)}$ ，一方で DSC 測定では冷却速度の影響を受 けやすいことや20)，試料サイズが小さいため確率論的に氷 核の発生が生じにくくなり測定值がより低温側にシフトす る可能性がある。よって過冷却点の評価については測定法 に十分に留意する必要がある。

(3) 試料の温度変化

熱電対計測した試料の温度変化の一例を Fig. 2 に示す. 試料の冷却速度は $0{ }^{\circ} \mathrm{C}$ から $-2^{\circ} \mathrm{C}$ の間で約 $2{ }^{\circ} \mathrm{C} / \mathrm{min}$ であ り, $0{ }^{\circ} \mathrm{C}$ から $-5{ }^{\circ} \mathrm{C}$ ま゙に要した時間は約 10 分であった. 一方, 昇温速度は $-5{ }^{\circ} \mathrm{C}$ から $0{ }^{\circ} \mathrm{C}$ の間で約 $10^{\circ} \mathrm{C} / \mathrm{min}$ となっ た。つぎに Fig. 2 (b) より，熱電対を挿入した試料は凍結 に伴う潜熱の放出をすることなく，1 週間 $-5{ }^{\circ} \mathrm{C}$ の品温を 保つことができた。これは，試料がー $5{ }^{\circ} \mathrm{C}$ に達してから昇 温に至るまでの庫内温度がー $4.7^{\circ} \mathrm{C} \sim-5.1{ }^{\circ} \mathrm{C}$ （標準偏差： $0.06{ }^{\circ} \mathrm{C} ）$ の間にあり温度変動が極めて小さかったことも要 因の一つと思われる
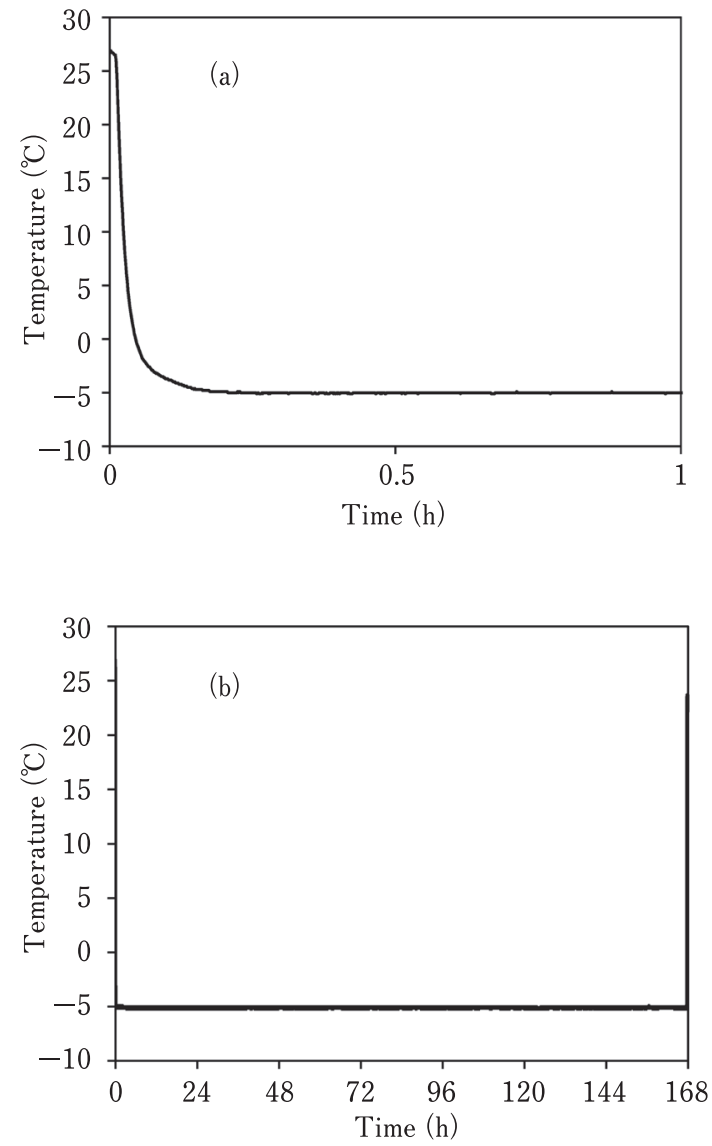

Fig. 2 Time-temperature profile of fresh cut spinach sample during supercooling test

(a) time-temperature profile from 0 to $1 \mathrm{~h}$, (b) time-temperature profile from 0 to $168 \mathrm{~h}$ (7 days). 
今回，試料の過冷却点は DSC 測定の結果から $-7.1{ }^{\circ} \mathrm{C}$ 以 下であることを記したが，熱電対計測の結果からも測定に 用いた試料の過冷却点は $-5{ }^{\circ} \mathrm{C}$ 以下であることが示唆され た。熱電対計測した試料は測定数も少なく，また $-5^{\circ} \mathrm{C} よ$ り低い温度まで冷却していないため, 過冷却点について DSC 測定值と直接比較することはできないが, 以上の結果

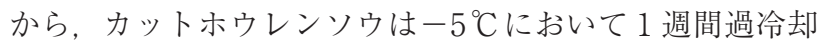
状態を保つことが可能であることが示された。

\section{2. 過冷却保存後の細胞膜状態および細胞活性の評価}

(1) 電気インピーダンス

F, DS および過冷却保存後の試料のインピーダンスの周 波数依存性を示す（Fig. 3).Fのインピーダンスは低周波 数域において高い值を示し，およそ $1 \mathrm{kHz}$ 近辺から急激に 減少し, DS は全周波数域で小さい值となった。この傾向 は，宮脇と四宮 ${ }^{5}$ が生鮮青果物試料とそれを凍結および解 凍処理した試料を比較した結果と同様である。過冷却保存 後の試料のインピーダンスをみると，全試料 48 サンプル 中 45 サンプル（以後，SC-1 と称す）は F と同様に低周波 数域において高い值を示しおよそ $1 \mathrm{kHz}$ 近辺から急激に減 少する周波数依存性を有したが, 残り 3 サンプル（以後, SC-2 と称す）はDS と同様に全周波数域で小さい值を示し た。

つぎに F, DS および過冷却保存後の試料（SC-1, SC-2） の Cole-Cole プロットを示す (Fig. 4). F と SC-1 は明確な Cole-Cole プロットの円弧を見ることができる，一方，DS と SC-2 は円弧が消失した. Cole-Cole プロットで見られる 円弧の収縮は青果物の細胞膜状態を示す指標として用いら れており ${ }^{7212222}$ ，特に凍結および解凍を経た青果物試料は細

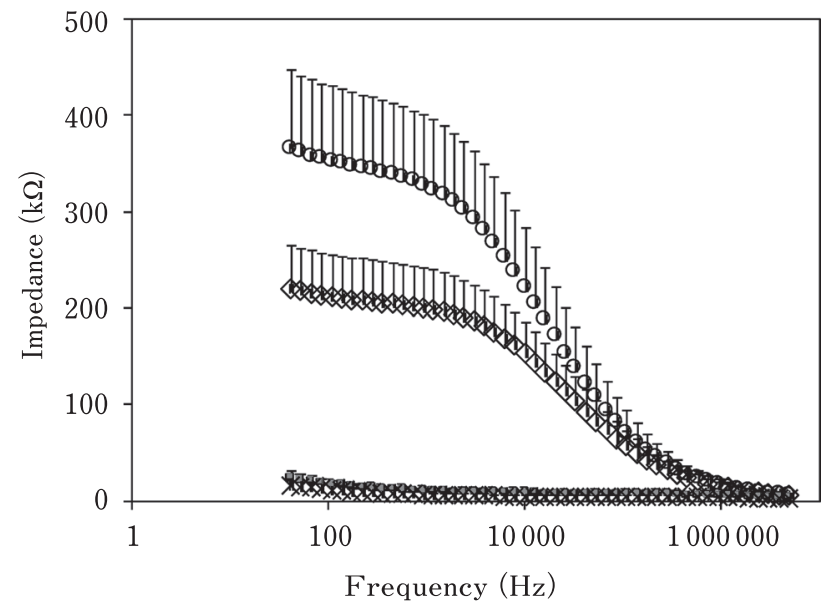

Fig. 3 Impedance of the fresh cut spinach supercooled at $-5{ }^{\circ} \mathrm{C}$

$\bigcirc, \mathrm{F}$ (fresh sample); $\times$, DS (frozen-thawed sample); $\diamond$, SC-1 (supercooled sample which has a high impedance at $1 \mathrm{kHz}$; 45/48 sample); . SC-2 (supercooled sample which has a low impedance at $1 \mathrm{kHz}$ as same as that of DS; $3 / 48$ sample). Each value represents the mean $\pm \mathrm{SD}$. Measurements were performed in triplicate.
胞膜構造が壊滅的に破壊されるため, インピーダンスの值 は生鮮試料と比べ激減し, 円弧は消失すると報告されてい る ${ }^{588}$. よって SC-1 は明確な円弧を有するため, 過冷却保存 後も試料の細胞膜は閉鎖性が保たれた状態 であると判断 される。しかし SC-1の円弧はFよりも小さいため, 過冷 却保存中に何らかの細胞膜状態の変化が生じたと思われ る.

Cole-Cole プロットを用いて実際の青果物を評価した研 究例として, 志塚と田川 ${ }^{7}$ は野菜（ダイコン, ニンジン, キュウリ）を氷結点以上となる $-1{ }^{\circ} \mathrm{C} て ゙ 1$ 週間から 30 日間 保存した結果, Cole-Cole プロットの円弧が小さくなるこ とを報告している。また加藤 ${ }^{23)}$ は，鮮度低下や内部損傷し た果実は生鮮果実と比べ Cole-Cole プロットの円弧の大き さが減少することを述べており，このことは細胞膜の劣化 により膜の電気特性が変わることによるものと推察してい る。今回の電気インピーダンス計測は，電極への接触面積 がカットホウレンソウの場合と既往の報告で用いられた立 方体試料とは異なるため, SC-1 が F よりも Cole-Cole プロッ トの円弧が収縮することについて単純に論じることはでき ないが，試料が過冷却中に鮮度低下した，あるいは内部損 傷した可能性は否定できないと考える。

つぎに SC-2 の Cole-Cole プロットを見ると円弧が消失 した。本研究では DS は細胞膜が致命的に損傷した試料の コントロールと定義したので, SC-2 の細胞膜の閉鎖性は維 持されていないと考えられる。

（2）細胞活性

過冷却保存後の試料（SC-1, SC-2），F，DS の細胞活性比 を Fig. 5 に示す.SC-2 は DS より有意差はないものの小さ

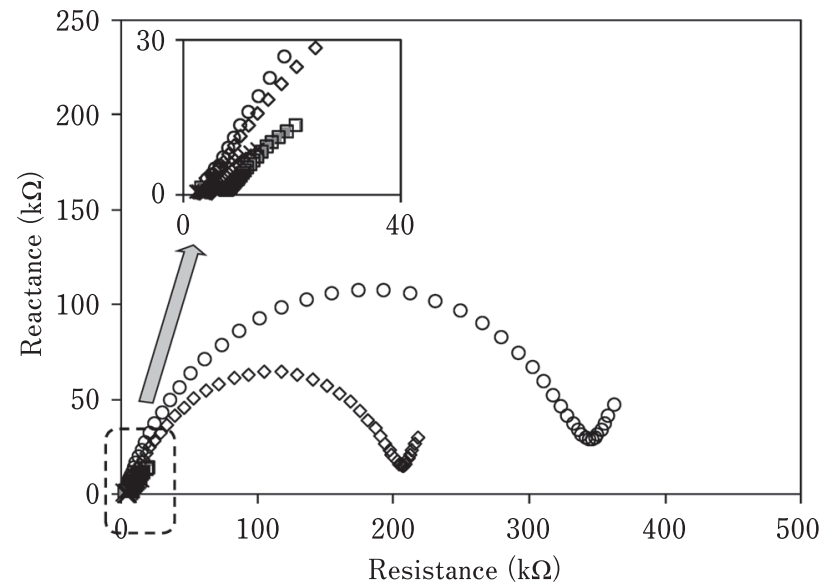

Fig. 4 Cole-Cole plots of the fresh cut spinach supercooled at $-5{ }^{\circ} \mathrm{C}$

$\bigcirc, \mathrm{F}$ (fresh sample); $\times$, DS (frozen-thawed sample); $\diamond$, SC-1 (supercooled sample which has a circular arc in the Cole-Cole plot; 45/48 sample); $\square$, SC-2 (supercooled sample which has no circular arc in the Cole-Cole plot; 3/48 sample).

Each value represents the mean. Measurements were performed in triplicate. 


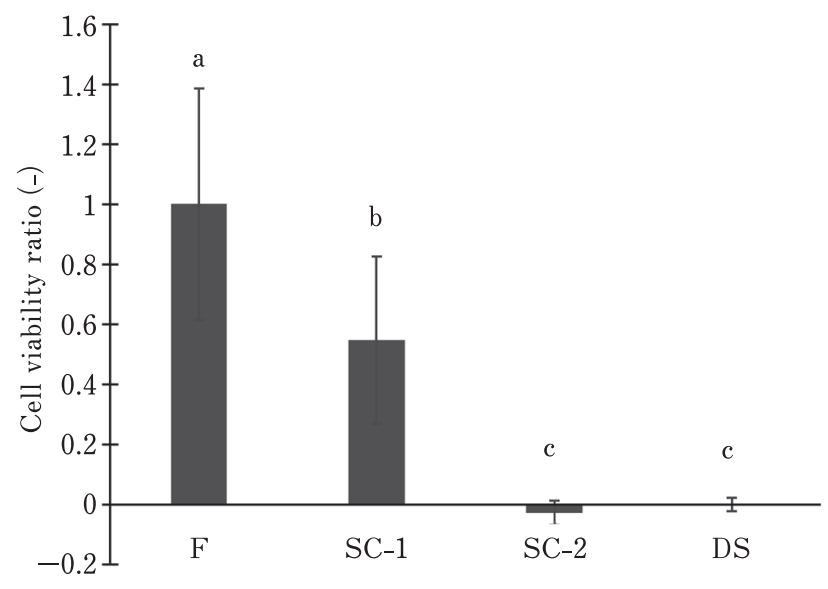

Fig. 5 Cell viability ratio of sample supercooled at $-5{ }^{\circ} \mathrm{C}$

F, fresh sample; SC-1, supercooled sample which has a circular arc in the Cole-Cole plot (45/48 sample); SC-2, supercooled sample which has no circular arc in the Cole-Cole plot (3/48 sample); DS, frozen-thawed sample.

Each value represents the mean $\pm \mathrm{SD}$. Means not sharing a common superscript differ significantly by Tukey-Kramer method $(\phi<0.05)$. Measurements were performed in triplicate.

い值となった。これは TTC 還元法により DSから抽出さ れたクロロフィル量が SC-2 と比較してわずかに多かった と考えられ，このことが吸光度の測定值にわずかに影響し たものと思われる.

今回, 細胞活性の測定において用いた TTC は細胞内で, ミトコンドリアの呼吸により生じた電子により還元され, 不溶性のフォルマザン (赤色色素) に変わる. このフォル マザンを抽出・定量して細胞活性を求める方法が TTC 還 元法であり植物生理学において凍結解凍後の生存を確認す る指標である ${ }^{24)}$. SC-2 の細胞活性は DS と有意差はなく同 程度の值であったことから，過冷却保存中に何らかの原因 で細胞活性が失われたと考える。その要因として過冷却解 消に伴う凍結傷害が考えられるが, それを確かめるには, 過冷却中に試料に過冷却を解消させる操作を行い, それが 細胞活性に与える影響などについて総合的に検討する必要 がある。

つぎにSC-1 は, 植物生理学的見地から細胞活性を有す ることを示すが，その細胞活性は F と比較して低い。これ はミトコンドリアの呼吸活性が何らかの要因で過冷却保存 中に低下したことによるものと考える. SC-1は, インピー ダンス計測でも F と比較して試料の Cole-Cole プロットの 円弧は小さくなったことが示されている。 今後は, 過冷却 保存温度や保存時間を変えて試料の細胞膜状態や細胞活性 の経時変化を計測し, 過冷却条件が青果物の鮮度や品質に 与える影響を検討する必要がある.

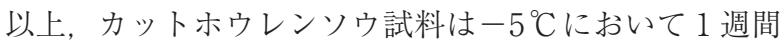
過冷却状態を保つことが可能であることを示した。今後, 青果物の過冷却保存の可能性を高めるには, 試料のサイズ
を大きくし，その過冷却点の分布および冷却速度が過冷却 点に与える影響について多くのデータを収集するととも に，過冷却保存が青果物の鮮度や品質に与える影響につい ても十分に検討する必要があると考える。

\section{要 約}

本研究では, カットホウレンソウを供試材料とし, その 質量モル濃度の測定值から水結点を算出するとともに, differential scanning calorimetry（DSC）冷却曲線より過冷 却点を計測した。 その結果，試料の水結点はー0.95 \pm 0.19 ${ }^{\circ} \mathrm{C}$, 過冷却点は $-7.1{ }^{\circ} \mathrm{C} \sim-16.8^{\circ} \mathrm{C}$ の範囲にあることが示

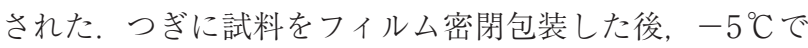
1 週間過冷却保存させた。過冷却保存後の試料の細胞膜状 態と細胞活性を電気インピーダンス計測法および TTC 還 元法を用いて評価した結果，全試料 48 サンプルのうち 45 サンプルにおいて，細胞膜の閉鎖性が保たれること，また 細胞活性を有することが示された。本研究は, カットホウ

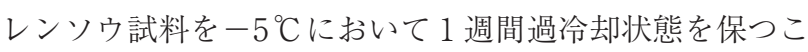
とが可能であることを示すが，過冷却保存は試料の細胞膜 状態を変化させ, 細胞活性を低下させることも示唆された.

本研究は，科学研究費補助金（基盤研究（B）16H05001 および挑戦的萌芽研究 16K15010）の助成により実施され たものである

\section{文献}

1) Helland, H.S., Leufvén, A., Bengtsson, G.B., Pettersen, M.K. Lea, P., and Wold, A.B. (2016). Storage of fresh-cut swede and turnip: Effect of temperature, including sub-zero temperature, and packaging material on sensory attributes, sugars and glucosinolates. Postharvest Biology and Technology, 111, 370-379.

2) Quang, T.N., Iwamura, K., Shrestha, R., and Sugimura, N. (2017). A study on supercooled storage of leaf lettuces produced in plant factory. Japan Journal of Food Engineering, 18 (1), $25-32$.

3) James, C., Seignemartin, V., and James, S.J. (2009). -The freezing and supercooling of garlic (Allium sativum L.). International Journal of Refrigeration, 32, 253-260.

4) James, C., Hanser, P., and James, S.J. (2011). Super-cooling phenomena in fruits, vegetables and seafoods. 11th International Congress on Engineering and Food (ICEF 2011), Athens, Greece, 22-26.

5) Miyawaki, O. and Shimiya, Y. (2002). Impedance analysis for freezing injury of cells and food. Cryobiology and Cryotechnology (Teion Seibustu Kogaku Kaishi), 48, 125-127（宮脇長 人, 四宮陽子, 細胞㧍よび食品の凍結傷害に対するイン ピーダンス解析, 低温生物工学会誌).

6) Wu, L., Ogawa, Y., and Tagawa, A. (2008). Electrical impedance spectroscopy analysis of eggplant pulp and effects of drying and freezing-thawing treatments on its impedance characteristics. Journal of Food Engineering, 87, 274-280.

7) Shizuka, J. and Tagawa, A. (2009). Evaluation by measurements of physical and electrical properties on fresh-cut vegetables stored for a long term using partial-freezing 
method. J. Jpn. Soc. Food. Sci. Technol. (Nippon Shokuhin Kagaku Kogaku Kaishi), 56, 453-462（志塚 淳, 田川彰男. Partial-freezing した長期貯蔵カット野菜の物理的, 電気的 評価, 日本食品科学工学会誌).

8）日本冷凍空調学会編 (2013). 冷凍空調便覽 $I V$ 巻食品 ·生物 編, 日本冷凍空調学会, pp. 13-16.

9) Ando, Y., Mizutani, K., and Wakatsuki, N. (2014). Electrical impedance analysis of potato tissues during drying. Journal of Food Engineering, 121, 24-31.

10) Steponkus, P.L. and Lanphear, F.O. (1967). Refinement of the triphenyl tetrazolium chloride method of determining cold injury. Plant Physiology, 42, 1427-1426.

11) Koide, S., Atungulu, G., Uemura, M., and Nishiyama, Y. (2005). Mechanical properties and viability of Japanese radish cylinders immersed in sodium chloride solutions. Biosystems Engineering, 92, 335-340.

12) Koide, S., Kumada, R., Hayakawa, K., Kawakami, I., Orikasa, T., Katahira, M., and Uemura, M. Survival of cut cabbage subjected to subzero temperatures. Acta Horticalturae. (in Press).

13) Ando, Y., Nei, D., Kono, S., and Nabetani, H. (2017). Current state and future issues of technology development connected with freezing and thawing of foods. J. Jpn. Soc. Food. Sci. Technol. (Nippon Shokuhin Kagaku Kogaku Kaishi), 64, 391-428（安藤泰雅，根井大介，河野晋治，鍋谷浩志，食品 の冷凍掞よび解凍に関する技術開発の現状と今後の課題, 日本食品科学工学会誌).

14) Morris, G.J. and Acton, E. (2013). Controlled ice nucleation in cryopreservation - A review. Cryobiology, 66, 85-92.

15) Zachariassen, K.E. and Kristiansen, E. (2000). Ice nucleation and antinucleation in nature. Cryobiology, 41, 257-279.

16) Kousksou, T., El Rhafiki, T., Mahdaoui, M., Bruel, P., and Zeraouli, Y. (2012). Crystallization of supercooled PCMs inside emulsions: DSC applications. Solar Energy Materials and Solar Cells, 107, 28-36.

17) Tanaka, A., Yamamoto, H., Hayashi, M., Amino, H., Kita, K., and Murase, N. (2011). DSC Analysis of freezing process of nematode Caenorhabditis elegans. Cryobiology and Cryotechnology (Teion Seibustu Kogaku Kaishi), 57, 91-94（田中 亜依, 山本紘之, 林 正和, 網野比佐子, 北 潔, 村勢則郎. DSC による線虫 Caenorhabdit ieslegans の凍結過程の解析, 低温生物工学会誌).

18) Sulpice, R., Gibon, Y., Bouchereau, A., and Larher, F. (1998). Exogenously supplied glycine betaine in spinach and rapeseed leaf discs: compatibility or non-compatibility?. Plant, Cell and Environment, 21, 1285-1292.

19) Suzuki, T., Takeuchi, Y., Masuda, K., Watanabe, M., Shirakashi,
R., Fukuda, Y., Tsuruta, T., Yamamoto, K., Koga, N., Hiruma, N., and Takai, K. (2011). Experimental investigation of effectiveness of magnetic field on food freezing process. Transactions of the Japan Society of Refrigerating and Air Conditioning Engineering. (Reitou Kuchou Gakkai Ronbunshu), 26, 371-386（鈴木 徹, 竹内友里, 益田和德, 渡辺 学, 白樫了, 福田 裕, 鶴田隆治, 山本和貴, 古賀 信光, 比留間直也, 一岡 順, 高井 皓. 食品凍結中に磁場 が及ぼす効果の実験的検証，日本冷凍空調学会論文集）

20) Takeuchi, M., Matsubara, H., Takahashi, T., Kosaka, Y., Kudoh, K., Watanabe, M., and Suzuki, T. (2015). Influence of freezing on the survival of third stage anisakis larvae. Transactions of the Japan Society of Refrigerating and Air Conditioning Engineering. (Reitou Kuchou Gakkai Ronbunshu), 32,199-206（竹内 萌, 松原 久, 高橋 匡, 小坂善信, 工 藤謙一, 渡辺 学, 鈴木 徹. アニサキス亜科 L3 幼虫の生 存に与える凍結の影響, 日本冷凍空調学会論文集).

21) Shizuka, J., Ogawa, Y., and Tagawa, A. (2008). Effects of freezing and thawing on the physical and electrical properties of dehydrated radish. J. Jpn. Soc. Food. Sci. Technol. (Nippon Shokuhin Kagaku Kogaku Kaishi), 55, 158-163 (志 塚 淳, 小川幸春, 田川彰男. 脱水ダイコンの物理的, 電気 的性質に及ぼす凍結㧍よび解凍操作の影響, 日本食品科学 工学会誌).

22) Uemura, T. and Tagawa, A. (2012). Effect of dehydration method on the physical properties of fresh-cut radish after freezing and after post-thaw rehydration in the dehydrofreezing technique. J. Jpn. Soc. Food. Sci. Technol. (Nippon Shokuhin Kagaku Kogaku Kaishi), 59, 115-121（植村泰介, 田川彰男。デハイドロフリージングにおける脱水法がカッ トダイコンの物理的性質および解凍・復水条件に及ぼす影 響, 日本食品科学工学会誌).

23) Kato, K. (1988). Nondestructive measurement of fruits quality by electrical impedance (Part 1) - Relation between impedance parameters and freshness -. J. JSAM (Nogyo Kikai Gakkaishi), 50 (6)，99-107 (加藤宏郎. 高周波イン ピーダンスによる農産物の非破壞鮮度判定（第 1 報）一青果 物の電気特性と内部品質および容量結合による非接触抵抗 測定一, 農業機械学会誌).

24）酒井 昭編（1987）. 「凍結保存一動物 ·植物 ·微生物一」, 朝倉書店, pp. 176-187.

\section{引用 URL}

i ) http://postharvest2017. sicongresos.com/posters/23.jpg (2018. 12. 15)

(平成 30 年 12 月 19 日受付, 平成 31 年 3 月 12 日受理) 